\title{
The effects of chemical remediation treatments on the extractability and speciation of cadmium and lead in contaminated soils
}

\author{
Z.S. Chen ${ }^{\mathrm{a}, *}$, G.J. Lee ${ }^{\text {a }}$, J.C. Liu ${ }^{\mathrm{a}, \mathrm{b}}$ \\ ${ }^{a}$ Graduate Institute of Agricultural Chemistry, National Taiwan University, Taipei 10617, Taiwan, ROC \\ b Department of Agricultural Chemistry, Taiwan Agricultural Research Institute, Taichung 41301, Taiwan, ROC
}

\begin{abstract}
Two rural soils contaminated by cadmium $(\mathrm{Cd})$ and lead $(\mathrm{Pb})$ were used to evaluate the effect of different chemical treatments on changes in speciation and extractability of $\mathrm{Cd}$ and $\mathrm{Pb}$, and in phytoavailability to wheat. Triplicates of seven chemical treatments were tested to compare and evaluate the remediation techniques for contaminated soils using pot experiments. Treatments applied were calcium carbonate, a high quantity of phosphate salt, hog composts, iron oxide, manganese oxide, zeolite, and unamended control. Wheat (Triticum aestivum) was planted in the different amended soils for a further one month to evaluate the effectiveness of treatments on uptake of $\mathrm{Cd}$ and $\mathrm{Pb}$ by the wheat shoots. Results indicated that addition of calcium carbonate, manganese oxide, or zeolite reduces the extractability of $\mathrm{Cd}$ or $\mathrm{Pb}$ in both soils, and significantly reduce the uptake of $\mathrm{Cd}$ and $\mathrm{Pb}$ by wheat shoots. Changes in the extractability and metal sequential fractionations indicate that the exchangeable (or available) form of $\mathrm{Cd}$ and $\mathrm{Pb}$ in two soils can be transformed into unavailable forms after these amendments. (c) 2000 Elsevier Science Ltd. All rights reserved.
\end{abstract}

\section{Introduction}

Heavy metal contamination in the natural environment is a major problem for human health and environmental quality (Purves, 1985; Chen et al., 1996; Ma and Rao, 1997). Geochemical forms of heavy metals existing in the soils affect their solubility, which may directly influence their phytoavailability (Xian, 1987). In last decade, many researchers have attempted to assess phytoavailability of heavy metals in contaminated soils using metal sequential extraction methods (Xian, 1987, 1989). Most of the heavy metals are persistent in soil because of their immobile nature. Cadmium is known as more mobile and soluble than many other metals in soils, bu $\mathrm{Pb}$ is well known to be relatively immobile and unavailable for plant uptake. Lead is a concern for human health when deposited on plant surfaces (Adriano,

\footnotetext{
${ }^{*}$ Corresponding author.

E-mail address: soilchen@ccms.ntu.edu.tw (Z.S. Chen).
}

1986). When agricultural soils are contaminated by heavy metals discharged from chemical plants, plant foliage is damaged and both growth rate and crop production are also retarded (Adriano, 1986). The effect of ionic strength and $\mathrm{pH}$ on the sorption of $\mathrm{Cd}$ and $\mathrm{Pb}$ is widely variable for different soils (Naidu et al., 1994). Higher concentrations of heavy metal soils may increase uptake of these elements by crops and potentially affect human health via food chains (Alloway, 1990). Cd and $\mathrm{Pb}$ may cause serious problems through food chains (Jackson and Alloway, 1992).

About 100 ha of rural soils contaminated with $\mathrm{Cd}$ and $\mathrm{Pb}$ were identified by the Environmental Protection Administration of Taiwan (EPA-Taiwan) in 1988. The concentration of $\mathrm{Cd}$ in brown rice growing at contaminated sites was higher than the critical health concentration of $\mathrm{Cd}(0.5 \mathrm{mg} / \mathrm{kg}$ dry weight $)$ issued by Department of Health of Taiwan (Chen, 1991; Chen et al., 1996). The mean total concentrations of $\mathrm{Cd}$ in brown rice and soils in two of these contaminated sites are $1.5-3.0 \mathrm{mg} / \mathrm{kg}$ and $4.7-378 \mathrm{mg} / \mathrm{kg}$. The mean total concentrations of $\mathrm{Pb}$ in 
brown rice and soils are $1.1-8.4 \mathrm{mg} / \mathrm{kg}$ and 25.8 $3140 \mathrm{mg} / \mathrm{kg}$, respectively (Chen, 1991; Chen et al., 1996). The contamination of $\mathrm{Cd}$ and $\mathrm{Pb}$ in other rural soils of Taiwan was also caused by the waste water discharged from the chemical plants in the industry park.

Many field and pot experiments on soil remediation techniques have been conducted at these two polluted sites (Chen et al., 1994; Lee and Chen, 1994; Wang et al., 1994; Chen and Lee, 1997). The soil remediation techniques include (1) chemical stabilization method to reduce the solubility of heavy metals by adding some nontoxic materials into the soils, (2) removal of polluted surface soils and replacement with clean soils, (3) covering the original polluted soil surface with clean soils, (4) on-site chemical leaching with acid agents, (5) dilution method, mixing polluted soils with surface and subsurface clean soils to reduce the concentration of heavy metals, or (6) phytoremediation by plants such as woody trees. The chemical stabilization method was evaluated as the most cost-effective remediation techniques for these contaminated sites, but techniques involving removal of polluted soils and addition of clean soils to the surface, or phytoremediation were also recommended (Chen et al., 1997).

Some chemical techniques for immobilizing metals in soils are application of dolomite, phosphates, or organic matter residues into the polluted soils to reduce the soluble concentration of heavy metals in soils by precipitation, adsorption, or complexation (Impens et al., 1991; Mench et al., 1994; Chen and Lee, 1997). Application of calcium carbonate materials significantly reduces the solubility of heavy metals in contaminated soils (McBride and Blasiak, 1979; Sommers and Lindsay, 1979; McBride, 1980; Kuo et al., 1985; Chen et al., 1997; Liu et al., 1998). Many reports also indicated that application of hydrous iron oxides or manganese oxides mixed into contaminated soils could reduce the concentration of soluble $\mathrm{Cd}$ or $\mathrm{Pb}$ in soils (McKenzie, 1980; Kuo and McNeal, 1984; Tiller et al., 1984; Khattak and Page, 1992; Mench et al., 1994; Chen et al., 1997).

The objectives of this study are (1) to compare the extractability of $\mathrm{Cd}$ and $\mathrm{Pb}$ in two contaminated soils treated with different chemical materials, (2) to evaluate the effectiveness of different chemical treatments on the uptake of $\mathrm{Cd}$ and $\mathrm{Pb}$ by wheat, and (3) to study the changes in the speciation of $\mathrm{Cd}$ and $\mathrm{Pb}$ by sequential fractionation methods after application of different chemical treatments.

\section{Materials and methods}

\subsection{The contaminated soils}

Two rice-growing soils, a clayey soil of the Chunghsing series at the Chungfu site and a sandy soil of the Tsaota series at the Tatan site, were selected for this study. These soils were contaminated with $\mathrm{Cd}$ and $\mathrm{Pb}$, which were discharged from two chemical plants in northern Taiwan (Chen, 1991; Chen et al., 1996). The area of the Chungfu contaminated site is about 80 ha, and that of the Tatan site is about 20 ha.

\subsection{Soil properties}

The surface soils $(0-20 \mathrm{~cm})$ of contaminated sites were sampled, air-dried, ground through a $2 \mathrm{~mm}$ sieve, and stored in plastic bags prior to laboratory analysis and use in pot experiments. Soil pH values were determined using glass electrodes in a soil:water ratio of 1:1 or a soil: $1 \mathrm{M} \mathrm{KCl}$ ratio of 1:2.5 (McLean, 1982). The particle size distribution of two soils was analyzed by the pipette method (Gee and Bauder, 1986). Organic carbon was determined by the Walkley-Black wet combustion method (Nelson and Sommers, 1982). Exchangeable cations ( $\mathrm{K}, \mathrm{Na}, \mathrm{Ca}$, and $\mathrm{Mg}$ ) and cation exchange capacity (CEC) were determined using ammonium acetate (pH 7) (Rhoades, 1982).

\subsection{Pot experiments}

Seven chemical treatments were used to compare and evaluate the effectiveness of chemical remediation techniques. Soils $(500 \mathrm{~g})$ were put in polyethylene pots. The soils were treated by one of the following methods: (1) calcium carbonate $\left(\mathrm{CaCO}_{3}\right)$ added to increase soil $\mathrm{pH}$ to 7.0 , (2) a high quantity of calcium phosphate (10 mg P), (3) $2 \%$ dry hog composts (10 g), (4) $1 \%$ iron oxide (5 g), (5) 1\% manganese oxide (5 g), (6) 1\% synthetic zeolite ( $5 \mathrm{~g}$, CEC of zeolite is $220 \mathrm{cmol}(+) / \mathrm{kg}$ zeolite, Sigma Chemical Company, USA), and (7) unamended control. Each treatment was performed in triplicates and incubated for two months at room temperature $\left(25^{\circ} \mathrm{C}\right)$. The water content of pot experiments was controlled by weighting the pot every three days. After incubation for two months, wheat (Triticum aestivum) was planted and an adequate amount of chemical fertilizer was also applied to the soils to support their normal growth. The amount of chemical fertilizers added to pots included $125 \mathrm{mg} \mathrm{N}$ (ammonium nitrate), $54 \mathrm{mg} \mathrm{K}$ (potasium sulfate), $53 \mathrm{mg} \mathrm{P}$ (calcium phosphate), and $30 \mathrm{mg} \mathrm{Mg}$ (magnesium sulfate). The soil $\mathrm{pH}$ was not effected by these treatments. The pots were laid out in a random complete block design (RCBD) under glasshouse conditions. Plants were grown for one month before harvesting. The height of the wheat shoot was only about $20 \mathrm{~cm}$. The harvested shoots were oven-dried at $60^{\circ} \mathrm{C}$ for $72 \mathrm{~h}$, then ground to pass a $40 \mu \mathrm{m}$ sieve. $0.5 \mathrm{~g}$ of ground plant material was digested with a $10 \mathrm{ml}$ conc. $\mathrm{H}_{2} \mathrm{SO}_{4}: \mathrm{HClO}_{4}$ mixture $(92: 8, \mathrm{v} / \mathrm{v})$ for $1 \mathrm{~h}$. The digestion solutions were filtered with a Whatman No. 42 filter paper and diluted 
to $50 \mathrm{ml}$. The concentration of $\mathrm{Cd}$ and $\mathrm{Pb}$ in the digests was determined by atomic adsorption spectrophotometry (Hitachi 180-30 type).

\subsection{Extraction of $\mathrm{Cd}$ and $\mathrm{Pb}$ in soils}

Extraction of $\mathrm{Cd}$ and $\mathrm{Pb}$ in the experimental soils was determined by several different extraction solutions for the seven treatments (Lakanen and Ervio, 1971; Norvell, 1984). These extraction reagents included distilled water (Mench et al., 1994), $0.1 \mathrm{M} \mathrm{Ca}\left(\mathrm{NO}_{3}\right)_{2}$ (Mench et al., 1994), 0.05 M EDTA (pH 7.0) (Norvell, 1984), 0.43 M HOAc (Mench et al., 1994), and 0.1 M $\mathrm{HCl}$ (EPA-ROC, 1994). The extraction solutions were filtered with a Whatman No. 42 filter paper and $<0.45 \mu \mathrm{m}$ millipore filter paper. Total concentrations of $\mathrm{Cd}$ and $\mathrm{Pb}$ in soils were determined by aqua regia digestion for $2 \mathrm{~h}$ and filtered with a Whatman No. 42 filter paper, then diluted to $50 \mathrm{ml}$ (EPA-ROC, 1994). The concentrations of $\mathrm{Cd}$ and $\mathrm{Pb}$ in the filtrate were determined by flame atomic absorption spectroscopy (Hitachi 180-30 type).

\subsection{Sequential extraction of $\mathrm{Cd}$ and $\mathrm{Pb}$ in soils}

Sequential extraction of $\mathrm{Cd}$ and $\mathrm{Pb}$ in contaminated soils treated with different amendments was undertaken (Mench et al., 1994). The procedure was conducted in four steps, assuming the forms of $\mathrm{Cd}$ and $\mathrm{Pb}$ extracted were (1) water soluble, exchangeable, weakly bounded with organic matter, and carbonate fractions, extracted with $0.11 \mathrm{M}$ HOAc by shaking for $16 \mathrm{~h}$, (2) occluded $\mathrm{Fe}$ or $\mathrm{Mn}$ oxide fraction, extracted with $0.1 \mathrm{M}$ hydroxy ammonium chloride by shaking for $16 \mathrm{~h}$, (3) organically bound and sulphide fractions, extracted with $30 \%$ hydrogen peroxide and $1 \mathrm{M}$ ammonium acetate by shaking for $16 \mathrm{~h}$, and (4) structurally bound in residual fraction, digested with aqua regia. Concentrations of $\mathrm{Cd}$ and $\mathrm{Pb}$ in these sequential fractions were deter- mined by atomic absorption spectrophotometry (Hitachi 180-30 type).

\subsection{Statistical analysis}

The variance and significant differences of concentrations of $\mathrm{Cd}$ and $\mathrm{Pb}$ in different chemical treated soils were analyzed by ANOVA (SAS Institute, 1982). The statistical significance in this analysis was defined at $P<0.1$.

\section{Results and discussion}

\subsection{Soil properties and concentrations of $\mathrm{Cd}$ and $\mathrm{Pb}$ at the contaminated sites}

Some selected soil properties of both contaminated sites are shown in Table 1 . Soil $\mathrm{pH}$ values were 5.0 $\left(\mathrm{H}_{2} \mathrm{O}\right)$ and $4.3(\mathrm{KCl})$ at Chungfu, and $5.4\left(\mathrm{H}_{2} \mathrm{O}\right)$ and 4.8 $(\mathrm{KCl})$ at Tatan. The organic carbon content and CEC of Chungfu soil were higher than those of Tatan soil. The other major difference in soil properties of these two polluted soils was the particle size distribution. The texture of Tatan soil is sandy loam with a low clay content $(135 \mathrm{~g} / \mathrm{kg})$ and high sand content $(742 \mathrm{~g} / \mathrm{kg})$. The texture of Chungfu soil is slit clay with a high clay content $(406 \mathrm{~g} / \mathrm{kg})$. The differences in CEC and clay content between the two contaminated soils could imply that Chungfu soil has a potentially stronger adsorption of heavy metals than Tatan soil.

Concentrations of $\mathrm{Cd}$ and $\mathrm{Pb}$ in Chungfu soil extracted by $0.1 \mathrm{M} \mathrm{HCl}$ are 4.56 and $11.3 \mathrm{mg} / \mathrm{kg}$; in Tatan soil, 15.3 and $398 \mathrm{mg} / \mathrm{kg}$, respectively. Total concentrations of $\mathrm{Cd}$ and $\mathrm{Pb}$ digested by aqua regia in contaminated Chungfu soil were 5.47 and $39.2 \mathrm{mg} / \mathrm{kg}$, and those of Tatan soils were 18.6 and $611 \mathrm{mg} / \mathrm{kg}$, respectively. These results indicated that Tatan soil was more

Table 1

The soil properties and concentration of $\mathrm{Cd}$ and $\mathrm{Pb}$ in both contaminated soils for pot experiments ${ }^{\mathrm{a}}$

\begin{tabular}{|c|c|c|c|c|c|c|c|c|c|c|c|}
\hline \multirow[t]{2}{*}{ Soil } & \multicolumn{2}{|l|}{$\mathrm{pH}$} & \multirow[b]{2}{*}{$\mathrm{OC}$} & \multicolumn{3}{|c|}{ Particle size analysis $(\mathrm{g} / \mathrm{kg})$} & \multirow[b]{2}{*}{ CEC } & \multicolumn{2}{|c|}{$\begin{array}{l}\text { Extractable }^{\mathrm{b}} \\
\text { (mg/kg dry soils) }\end{array}$} & \multicolumn{2}{|c|}{$\begin{array}{l}\text { Total content }{ }^{\mathrm{c}} \\
\text { (mg/kg dry soils) }\end{array}$} \\
\hline & $\mathrm{H}_{2} \mathrm{O}$ & $\mathrm{KCl}$ & & sand & silt & clay & & $\mathrm{Cd}$ & $\mathrm{Pb}$ & $\mathrm{Cd}$ & $\mathrm{Pb}$ \\
\hline $\begin{array}{l}\text { Chu- } \\
\text { ngfu }\end{array}$ & 5.0 & 4.3 & 24 & 113 & 481 & 406 & 12.4 & $\begin{array}{l}4.56 \\
(8 \%)^{d}\end{array}$ & $\begin{array}{l}11.3 \\
(10 \%)\end{array}$ & $\begin{array}{l}5.47 \\
(10 \%)\end{array}$ & $\begin{array}{l}39.2 \\
(8 \%)\end{array}$ \\
\hline Tatan & 5.4 & 4.8 & 13 & 742 & 123 & 135 & 4.5 & $\begin{array}{l}15.3 \\
(8 \%)\end{array}$ & $\begin{array}{l}398 \\
(5 \%)\end{array}$ & $\begin{array}{l}18.6 \\
(10 \%)\end{array}$ & $\begin{array}{l}611 \\
(12 \%)\end{array}$ \\
\hline
\end{tabular}

OC: organic carbon content $\mathrm{g} / \mathrm{Kg}$; CEC: cation exchangeable capacity $(\mathrm{cmol}(+) / \mathrm{kg}$ dry soils).

${ }^{\mathrm{a}}$ Pot experiments are triplicates.

${ }^{\mathrm{b}}$ Extracted using $0.1 \mathrm{M} \mathrm{HCl}$.

${ }^{\mathrm{c}}$ Digestion using aqua regia.

${ }^{\mathrm{d}} \mathrm{CV}(\%)$ : coefficient of variation $(\%)$ in the parenthesis. 
contaminated than Chungfu soil (Chen, 1991; Chen et al., 1996).

\subsection{Extraction of $\mathrm{Cd}$ and $\mathrm{Pb}$}

The extracted concentrations of heavy metals in these two polluted soils treated with different amendments can be compared and evaluated by different extractants, such as distilled water, $0.1 \mathrm{M} \mathrm{Ca}\left(\mathrm{NO}_{3}\right)_{2}, 0.05 \mathrm{M}$ EDTA (pH 7.0), $0.43 \mathrm{M} \mathrm{HOAc}$, and $0.1 \mathrm{M} \mathrm{HCl}$. Table 2 indicated that there were significant decreases in the extractability of $\mathrm{Cd}$ following amendment with calcium carbonate, manganese oxide or zeolite; this is based on the concentrations extracted by EDTA and HOAc $(P<0.1)$. There are no significant differences in $\mathrm{Cd}$ extraction from Tatan soil extracted with $\mathrm{Ca}\left(\mathrm{NO}_{3}\right)_{2}$ or $\mathrm{HCl}$. These results are at variance with some other published papers which indicate that application of lime can significantly reduce the solubility of $\mathrm{Cd}$ in contaminated soil, especially at slightly contaminated sites (McBride, 1980; Christensen, 1984; Kuo et al., 1985; Mench et al., 1994; Liu et al., 1998). Other studies have indicated that application of hydrous iron or manganese oxides can significantly reduce solubility of $\mathrm{Cd}$ in soil (Kuo and McNeal, 1984; Tiller et al., 1984; Fu et al., 1991; Khattak and Page, 1992; Mench et al., 1994; Lee, 1996). In the present study, the extraction of $\mathrm{Cd}$ in soils treated with calcium carbonate to increase soil $\mathrm{pH}$ to 7 is almost lowest than other amendments, therefore soil $\mathrm{pH}$ is regarded as a key factor controlling extractibility of $\mathrm{Cd}$ and $\mathrm{Pb}$ in both contaminated soils (Table 2).
Table 3 also indicates that a significant decrease in extractable $\mathrm{Pb}$ concentration in soils following treatments with either calcium carbonate, manganese oxide or zeolite $(P<0.1)$. The changes in extractability of $\mathrm{Pb}$ were based on $\mathrm{Ca}\left(\mathrm{NO}_{3}\right)_{2}$ and EDTA extracts for Chungfu soil and $\mathrm{Ca}\left(\mathrm{NO}_{3}\right)_{2}$, EDTA, and HOAc extracts for Tatan soil. These results agree with other findings that application of lime (McBride, 1980; Kuo et al., 1985; Mench et al., 1994; Liu et al., 1998) and hydrous iron or manganese oxides (Kuo and McNeal, 1984; Tiller et al., 1984; Khattak and Page, 1992; Mench et al., 1994; Lee, 1996) can significantly reduce solubility of $\mathrm{Pb}$ in soil. It was also indicated that application of zeolite could significantly reduce the solubility of $\mathrm{Pb}$ in the soil (Gworek, 1992). The extractable $\mathrm{Pb}$ concentration in seriously contaminated Tatan soil was elevated $(>250 \mathrm{mg} / \mathrm{kg}$ ).

\subsection{Uptake of $\mathrm{Cd}$ and $\mathrm{Pb}$ by wheat}

Uptake of $\mathrm{Cd}$ and $\mathrm{Pb}$ by wheat (Triticum aestivum) grown in the two polluted soils amended with different materials is shown in Table 4. Results indicate that treatment with calcium carbonate, manganese oxide or zeolite can significantly reduce plant uptake of $\mathrm{Cd}$ and $\mathrm{Pb}(P<0.1)$. Table 4 also shows that treatment with iron oxide does not affect plant uptake of $\mathrm{Cd}$ and $\mathrm{Pb}$. From these pot experiments, it was concluded that remediation with manganese oxide, calcium carbonate or zeolite can significantly reduce uptake of $\mathrm{Cd}$ and $\mathrm{Pb}$ in wheat.

Table 2

Cadmium concentrations extracted by different extractants in both contaminated soils treated with different amendments

\begin{tabular}{|c|c|c|c|c|c|}
\hline \multirow[t]{2}{*}{ Treatment $^{\mathrm{a}}$} & \multicolumn{5}{|c|}{ Cd concentrations extracted by single extraction solution ( $\mathrm{mg} / \mathrm{kg}$ dry soils) } \\
\hline & Water & $\mathrm{Ca}\left(\mathrm{NO}_{3}\right)_{2}$ & EDTA & HOAc & $\mathrm{HCl}$ \\
\hline \multicolumn{6}{|l|}{ Chungfu soil } \\
\hline Control & ND & $4.31 \mathrm{a}$ & $4.09 \mathrm{a}$ & $3.75 \mathrm{a}$ & $4.56 \mathrm{a}$ \\
\hline FO & ND & $4.11 \mathrm{~b}$ & $4.09 \mathrm{a}$ & $3.13 \mathrm{bc}$ & $4.45 \mathrm{ab}$ \\
\hline MO & ND & $4.11 \mathrm{~b}$ & $3.86 \mathrm{ab}$ & $2.92 \mathrm{c}$ & $4.23 \mathrm{bc}$ \\
\hline $\mathrm{CaCO}_{3}$ & ND & $3.95 \mathrm{~b}$ & $3.42 \mathrm{c}$ & $3.13 \mathrm{bc}$ & $4.17 \mathrm{c}$ \\
\hline Phosphate & ND & $3.34 \mathrm{~b}$ & $3.98 \mathrm{ab}$ & $3.34 \mathrm{~b}$ & $4.34 \mathrm{abc}$ \\
\hline Compost & ND & $3.13 \mathrm{~b}$ & $3.87 \mathrm{ab}$ & $3.13 \mathrm{bc}$ & $4.56 \mathrm{a}$ \\
\hline Zeolite & ND & $4.05 \mathrm{~b}$ & $3.76 \mathrm{~b}$ & $2.92 \mathrm{c}$ & $4.17 \mathrm{c}$ \\
\hline \multicolumn{6}{|l|}{ Tatan soil } \\
\hline Control & $0.12 \mathrm{a}$ & $13.7 \mathrm{a}$ & $15.1 \mathrm{a}$ & $17.0 \mathrm{a}$ & $15.3 \mathrm{a}$ \\
\hline FO & $0.12 \mathrm{a}$ & $13.7 \mathrm{a}$ & $15.1 \mathrm{a}$ & $16.0 \mathrm{bc}$ & $15.3 \mathrm{a}$ \\
\hline MO & $0.12 \mathrm{a}$ & $13.7 \mathrm{a}$ & $14.0 \mathrm{ab}$ & $15.3 \mathrm{c}$ & $15.8 \mathrm{a}$ \\
\hline $\mathrm{CaCO}_{3}$ & $\mathrm{ND} b$ & $13.7 \mathrm{a}$ & $11.3 \mathrm{c}$ & $16.2 \mathrm{c}$ & $15.8 \mathrm{a}$ \\
\hline Phosphate & $\mathrm{ND} b$ & $13.2 \mathrm{a}$ & $14.0 \mathrm{ab}$ & $16.2 \mathrm{bc}$ & $15.8 \mathrm{a}$ \\
\hline Compost & $\mathrm{ND} b$ & $13.2 \mathrm{a}$ & $12.4 \mathrm{bc}$ & $14.9 \mathrm{c}$ & $15.3 \mathrm{a}$ \\
\hline Zeolite & $\mathrm{ND} b$ & $13.7 \mathrm{a}$ & $12.9 \mathrm{bc}$ & $17.0 \mathrm{ab}$ & $15.8 \mathrm{a}$ \\
\hline
\end{tabular}

Data are expressed as mean value of triplicates. Difference letters in a column indicate significant difference between treatments at $P=0.1$.

${ }^{\mathrm{a}}$ FO: iron oxides; MO: manganese oxides; ND: not detectable. 
Table 3

Lead concentrations extracted by different extractants in both contaminated soils treated with different amendments

\begin{tabular}{|c|c|c|c|c|c|}
\hline \multirow[t]{2}{*}{ Treatment $^{\mathrm{a}}$} & \multicolumn{5}{|c|}{$\mathrm{Pb}$ concentration extracted by single extraction solution (mg/kg dry soils) } \\
\hline & Water & $\mathrm{Ca}\left(\mathrm{NO}_{3}\right)_{2}$ & EDTA & HOAc & $\mathrm{HCl}$ \\
\hline \multicolumn{6}{|l|}{ Chungfu soil } \\
\hline Control & ND & $14.6 \mathrm{a}$ & $12.2 \mathrm{a}$ & $1.27 \mathrm{a}$ & $11.3 \mathrm{a}$ \\
\hline FO & ND & $12.9 \mathrm{~b}$ & $10.5 \mathrm{ab}$ & $1.27 \mathrm{a}$ & $11.3 \mathrm{a}$ \\
\hline MO & ND & $8.59 \mathrm{c}$ & $6.13 \mathrm{c}$ & $1.27 \mathrm{a}$ & $6.14 \mathrm{~b}$ \\
\hline $\mathrm{CaCO}_{3}$ & ND & $12.9 \mathrm{~b}$ & $11.3 \mathrm{ab}$ & $1.27 \mathrm{a}$ & $10.5 \mathrm{a}$ \\
\hline Phosphate & ND & $13.3 \mathrm{ab}$ & $12.2 \mathrm{a}$ & $1.27 \mathrm{a}$ & $11.3 \mathrm{a}$ \\
\hline Compost & ND & $14.2 \mathrm{ab}$ & $10.5 \mathrm{ab}$ & $1.27 \mathrm{a}$ & $11.3 \mathrm{a}$ \\
\hline Zeolite & ND & $12.9 \mathrm{~b}$ & $8.72 \mathrm{~b}$ & $1.27 \mathrm{a}$ & $10.5 \mathrm{a}$ \\
\hline \multicolumn{6}{|l|}{ Tatan soil } \\
\hline Control & $1.31 \mathrm{a}$ & $347 \mathrm{a}$ & $415 \mathrm{a}$ & $282 \mathrm{a}$ & $398 \mathrm{a}$ \\
\hline FO & $\mathrm{ND} b$ & $343 \mathrm{a}$ & $381 \mathrm{~b}$ & $282 \mathrm{a}$ & $398 \mathrm{a}$ \\
\hline MO & $\mathrm{ND} b$ & $330 \mathrm{~b}$ & $381 \mathrm{~b}$ & $235 \mathrm{c}$ & $398 \mathrm{a}$ \\
\hline $\mathrm{CaCO}_{3}$ & $\mathrm{ND} b$ & $343 \mathrm{a}$ & $389 \mathrm{~b}$ & $282 \mathrm{a}$ & $398 \mathrm{a}$ \\
\hline Phosphate & $\mathrm{ND} b$ & $343 \mathrm{a}$ & $381 \mathrm{~b}$ & $275 \mathrm{~b}$ & 398 a \\
\hline Compost & $\mathrm{ND} b$ & $339 \mathrm{ab}$ & $398 \mathrm{ab}$ & $242 \mathrm{c}$ & $398 \mathrm{a}$ \\
\hline Zeolite & $1.31 \mathrm{a}$ & $347 \mathrm{a}$ & $372 \mathrm{~b}$ & $275 \mathrm{~b}$ & $372 \mathrm{~b}$ \\
\hline
\end{tabular}

Data and symbol are expressed as Table 2 .

${ }^{\mathrm{a}}$ FO: iron oxides; MO: manganese oxides; ND: not detectable.

Table 4

Uptake of $\mathrm{Cd}$ and $\mathrm{Pb}$ in wheat shoot grown in two contaminated soils treated with different amendments

\begin{tabular}{lll}
\hline Treatments $^{\mathrm{a}}$ & $\begin{array}{l}\text { Chungfu soil } \\
\text { (mg (dry } \\
\text { weight) total } \\
\text { taken up/pot) }\end{array}$ & $\begin{array}{l}\text { Tatan soil } \\
\text { (mg (dry } \\
\text { weight) total } \\
\text { taken up/pot) }\end{array}$ \\
\hline Cadmium & & \\
Control & $0.05 \mathrm{a}$ & $0.13 \mathrm{a}$ \\
$\mathrm{FO}$ & $0.02 \mathrm{bcd}$ & $0.13 \mathrm{ab}$ \\
$\mathrm{MO}$ & $0.02 \mathrm{bcd}$ & $0.10 \mathrm{~b}$ \\
$\mathrm{CaCO}$ & $0.01 \mathrm{~d}$ & $0.10 \mathrm{~b}$ \\
Phosphate & $0.04 \mathrm{ab}$ & $0.12 \mathrm{ab}$ \\
Compost & $0.03 \mathrm{abc}$ & $0.12 \mathrm{ab}$ \\
Zeolite & $0.02 \mathrm{~cd}$ & $0.06 \mathrm{c}$ \\
Lead & & \\
Control & $0.14 \mathrm{a}$ & $0.31 \mathrm{a}$ \\
FO & $0.02 \mathrm{~b}$ & $0.25 \mathrm{ab}$ \\
MO & $0.05 \mathrm{~b}$ & $0.21 \mathrm{~b}$ \\
CaCO & $0.05 \mathrm{~b}$ & $0.15 \mathrm{c}$ \\
Phosphate & $0.02 \mathrm{~b}$ & $0.23 \mathrm{~b}$ \\
Compost & $0.02 \mathrm{~b}$ & $0.18 \mathrm{bc}$ \\
Zeolite & $0.02 \mathrm{~b}$ & $0.14 \mathrm{c}$ \\
\hline
\end{tabular}

Data are expressed as mean value of triplicates. Difference letters in a column indicate significant difference between treatments at $P=0.1$.

${ }^{\mathrm{a}} \mathrm{FO}$ : iron oxides; MO: manganese oxides.

\subsection{Sequential extraction studies}

The concentrations of $\mathrm{Cd}$ and $\mathrm{Pb}$ found in different sequential extractions following treatment of the unamended soil are shown in Table 5. Results indicate that the soluble form of $\mathrm{Cd}$, ranging from $56 \%$ to $76 \%$ of the total content, is the major chemical form in both contaminated soils, and the minor fractions are the organically bound form, sulphide form, and residual form. Table 5 also indicates that the residual fraction of $\mathrm{Pb}$ is the major chemical form ( $67 \%$ of total content) in Chungfu soil, which possess low $\mathrm{Pb}$ content, but the other three forms (which are soluble form, $\mathrm{Fe}$ - and $\mathrm{Mn}$ bound form, and organically bound and sulphide fraction) of $\mathrm{Pb}$ are of almost equal importance $(20 \%-30 \%$ of the total content for each form) in Tatan soil with elevated $\mathrm{Pb}$ content.

The changes of sequential fractions of $\mathrm{Cd}$ in Chungfu soil and Tatan soils after incubation for two months are shown in Table 6 Results indicate that exchangeable form of $\mathrm{Cd}$, extractable by ammonium acetate, in Chungfu and Tatan soils amended with calcium carbonate or zeolite can be transformed to other three bounded forms. It was concluded that the forms of $\mathrm{Pb}$ in Chungfu soil amended with different materials were only changed to unavailable forms including organic, sulphide and residue fractions. The fraction of available form of $\mathrm{Pb}$ in Chungfu soil is very low $(<1 \%)$. The exchangeable form of high level of $\mathrm{Pb}$ in Tatan soil can be slightly transformed to other three unavailable forms after amendments with manganese oxide, calcium carbonate, compost or zeolite. The changes of metal sequential extraction of $\mathrm{Cd}$ and $\mathrm{Pb}$ in both contaminated soils indicated that the exchangeable (or available) form of $\mathrm{Cd}$ and $\mathrm{Pb}$ can be significantly transformed to unavailable form after amendment with manganese oxide, calcium carbonate or zeolite. 
Table 5

The distribution of metal sequential fractionation of cadmium and lead in two contaminated soils before treatments

\begin{tabular}{|c|c|c|c|c|c|c|c|}
\hline \multirow[t]{2}{*}{ Soil } & \multicolumn{4}{|c|}{$\begin{array}{l}\text { Metal sequential fractionations by different reagents }(\mathrm{mg} / \mathrm{kg} \\
\text { dry soils) }\end{array}$} & \multirow{2}{*}{$\begin{array}{l}\text { Sum of } \\
\text { fractions } \\
(\mathrm{mg} / \mathrm{kg} \text { dry } \\
\text { soils) }\end{array}$} & \multirow{2}{*}{$\begin{array}{l}\text { Total content } \\
\text { of elements } \\
\text { (mg/kg dry } \\
\text { soils) }\end{array}$} & \multirow{2}{*}{$\begin{array}{l}\text { Recovery of } \\
\text { summation }^{\mathrm{a}} \\
(\%)\end{array}$} \\
\hline & $\overline{\mathrm{HOAc}}$ & $\mathrm{HONH}_{3} \mathrm{Cl}$ & $\begin{array}{l}\mathrm{H}_{2} \mathrm{O}_{2}+ \\
\mathrm{NH}_{4} \mathrm{OAc}\end{array}$ & $\mathrm{AR}$ & & & \\
\hline & \multicolumn{7}{|l|}{ Cadmium } \\
\hline & Chungfu & $\begin{array}{l}3.26 \\
(56 \%)^{b}\end{array}$ & $1.86(32 \%)$ & $\mathrm{ND}(<1 \%)$ & $0.70(12 \%)$ & $5.82(100 \%)$ & 5.47 \\
\hline 106 & Tatan & $\begin{array}{l}16.3 \\
(76 \%)^{b}\end{array}$ & $3.19(15 \%)$ & $1.14(5 \%)$ & $0.91(4 \%)$ & $21.5(100 \%)$ & 18.6 \\
\hline 115 & \multicolumn{7}{|l|}{ Lead } \\
\hline Chungfu & ND $(<1 \%)$ & $\mathrm{ND}(<1 \%)$ & $7.25(33 \%)$ & $14.5(67 \%)$ & $\begin{array}{l}21.8 \\
(100 \%)\end{array}$ & 39.2 & 56 \\
\hline Tatan & $187(30 \%)^{\mathrm{b}}$ & $148(24 \%)$ & $162(26 \%)$ & $126(20 \%)$ & $623(100 \%)$ & 611 & 101 \\
\hline
\end{tabular}

AR: total contents of elements digested by aqua regia. ND: non-detectable (lower than method detection limit, MDL). The method detection limit of $\mathrm{Cd}$ and $\mathrm{Pb}$ are 0.2 and $1.00 \mathrm{mg} / \mathrm{kg}$ dry soils.

${ }^{\mathrm{a}}$ The percentage is the ratio of sum of four fractions divided the total content of metal.

${ }^{\mathrm{b}}$ Percentage in the parenthesis is the percentage of ratio of concentration of each fraction divided to sum of four fractions.

Table 6

The relative distribution (\%) of sequential extraction of cadmium and lead in both contaminated soils after different amendments

\begin{tabular}{|c|c|c|c|c|c|c|}
\hline \multirow[t]{2}{*}{ Soil } & \multirow[t]{2}{*}{ Treatments } & \multicolumn{4}{|c|}{ Metal sequential fractionations by different reagents $(\%)$} & \multirow{2}{*}{$\begin{array}{l}\text { Recovery of } \\
\text { summation }\end{array}$} \\
\hline & & HOAc & $\mathrm{HONH}_{3} \mathrm{Cl}$ & $\mathrm{H}_{2} \mathrm{O}_{2}+\mathrm{NH}_{4} \mathrm{OAc}$ & $\mathrm{AR}$ & \\
\hline \multicolumn{7}{|l|}{ Cadmium } \\
\hline \multirow[t]{7}{*}{ Chungfu } & Control & $54^{\mathrm{b}}$ & 20 & 13 & 13 & 119 \\
\hline & $\mathrm{FO}$ & 50 & 25 & 13 & 13 & 118 \\
\hline & MO & 50 & 28 & 14 & 7 & 110 \\
\hline & $\mathrm{CaCO}_{3}$ & 43 & 28 & 14 & 14 & 110 \\
\hline & Phosphate & 62 & 9 & 9 & 19 & 90 \\
\hline & Compost & 55 & 14 & 14 & 18 & 95 \\
\hline & Zeolite & 48 & 17 & 17 & 17 & 99 \\
\hline \multirow[t]{7}{*}{ Tatan } & Control & 75 & 13 & 6 & 6 & 114 \\
\hline & FO & 76 & 12 & 6 & 6 & 110 \\
\hline & MO & 73 & 13 & 7 & 7 & 111 \\
\hline & $\mathrm{CaCO}_{3}$ & 65 & 16 & 11 & 9 & 112 \\
\hline & Phosphate & 72 & 14 & 7 & 7 & 107 \\
\hline & Compost & 68 & 17 & 9 & 7 & 107 \\
\hline & Zeolite & 73 & 12 & 9 & 7 & 114 \\
\hline \multicolumn{7}{|l|}{ Lead } \\
\hline \multirow[t]{7}{*}{ Chungfu } & Control & $<1$ & $<1$ & 38 & 62 & 93 \\
\hline & FO & $<1$ & $<1$ & 50 & 50 & 93 \\
\hline & MO & $<1$ & $<1$ & 57 & 43 & 94 \\
\hline & $\mathrm{CaCO}_{3}$ & $<1$ & $<1$ & 50 & 50 & 93 \\
\hline & Phosphate & $<1$ & $<1$ & 33 & 67 & 85 \\
\hline & Compost & $<1$ & $<1$ & 33 & 67 & 89 \\
\hline & Zeolite & $<1$ & $<1$ & 33 & 67 & 92 \\
\hline \multirow[t]{7}{*}{ Tatan } & Control & 29 & 24 & 26 & 20 & 90 \\
\hline & $\mathrm{FO}$ & 27 & 24 & 28 & 21 & 92 \\
\hline & MO & 21 & 25 & 32 & 22 & 88 \\
\hline & $\mathrm{CaCO}_{3}$ & 24 & 24 & 30 & 22 & 88 \\
\hline & Phosphate & 28 & 25 & 27 & 21 & 86 \\
\hline & Compost & 21 & 25 & 31 & 23 & 84 \\
\hline & Zeolite & 25 & 23 & 31 & 21 & 86 \\
\hline
\end{tabular}

AR: total contents of elements digested by aqua regia.

${ }^{a}$ The percentage is the ratio of sum of four fractions divided to total content of metal.

${ }^{\mathrm{b}}$ Percentage is the percentage of ratio of concentration of each fraction divided to sum of four fractions. 


\section{Conclusions}

1. There are significant decreases in the extractability of $\mathrm{Cd}$ and $\mathrm{Pb}$ in both contaminated soils following amendments with calcium carbonate, manganese oxide, or zeolite $(P<0.1)$.

2. The chemical remediation methods, using manganese oxide, calcium carbonate or zeolite, can significantly reduce the uptake of $\mathrm{Cd}$ and $\mathrm{Pb}$ in wheat shoots $(P<0.1)$.

3. Exchangeable (or available) form of $\mathrm{Cd}$ and $\mathrm{Pb}$ in both contaminated soils can be transformed to unavailable forms after amendment with $1 \%$ manganese oxide or zeolite, or treatment with calcium carbonate to increase the soil $\mathrm{pH}$ to 7 .

\section{Acknowledgements}

Funding of this research was supported by National Science Council, Executive Yuan, Republic of China (grants numbers of NSC 85-2621-P-002-004 and NSC 86-2621-P-002-006).

\section{References}

Adriano, D.C., 1986. Trace Elements in the Terrestrial Environment. Springer, New York, USA.

Alloway, B.J., 1990. Heavy Metals in Soils, First ed., Blackie, London, UK.

Chen, Z.S., 1991. Cadmium and lead contamination of soils near plastic stabilizing materials producing plants in northern Taiwan. Water, Air, and Soil Pollu. 57-58, 745-754.

Chen, Z.S., Lao, S.L., Wu, H.C., 1994. Summary analysis and assessment of rural soils contaminated with Cd in Taoyuan. Project report of Scientific Technology Advisor Group, Executive Yuan. Taipei, Taiwan, p. 153 (in Chinese, with English abstract).

Chen, Z.S., Lee, D.Y., 1997. Evaluation of remediation techniques on two cadmium polluted soils in Taiwan. In: Iskandar, A., Adriano, D.C. (Eds.), Remediation of Soils Contaminated with Metals. Book Chapter of Special Volume of Second International Conference on the Biogeochemistry of Trace Elements. (5-10 September, 1993, Taipei, Taiwan). Science Review, London, pp. 209-223.

Chen, Z.S., Lee, D.Y., Lin, C.F., Lo, S.L., Wang, Y.P., 1996. Contamination of rural and urban soils in Taiwan. In: Naidu, R., Kookuna, R.S., Oliver, D.P., Rogers, S., McLaughlin, M.J. (Eds.), Contaminants and the Soil Environment in the Australasia-Pacific Region. Proceedings of the First Australasia-Pacific Conference on Contaminants and Soil Environment in the Australasia-Pacific Region. Adelaide, Australia, 18-23 February, Kluwer Academic Publishers, Boston, London, pp. 691-709.

Chen, Z.S., Lee, G.J., Liu, J.C., 1997. Chemical remediation treatments for soils contaminated with cadmium and lead.
In: Proceedings of the Fourth International Conference on the Biogeochemistry of Trace Elements, June 22-26, 1997, Berkeley, California, USA, pp. 421-422.

Christensen, T.H., 1984. Cadmium soil sorption at low concentrations: Effect of time cadmium load $\mathrm{pH}$, and calcium. Water, Air, and Soil Pollu. 21, 106-114.

EPA-ROC, 1994. The standard methods for determination of heavy metals in soils and plants. National Institute of Environmental Analysis of EPA-ROC, Taipei, Taiwan (in Chinese).

Fu, G., Allen, H.E., Cowan, C.E., 1991. Adsorption of cadmium and copper by manganese oxide. Soil Sci. 152, $72-81$.

Gee, G.W., Bauder, J.W., 1986. Particle-size analysis. In: Klute, A. (Ed.), Methods of Soil Analysis, Part 1. Physical and Mineralogical Methods, Second ed., Agronomy Monography No. 9, pp. 383-411.

Gworek, B., 1992. Lead inactivation in soils by zeolites. Plant and Soil 143, 71-74.

Impens, R., Fagot, J., Avril, C., 1991. Gestion des Sols Contaminés par les Métaux Lourds. Association Francaise Interprofessionnelle du Cadmium, Paris, France.

Jackson, A.P., Alloway, B.J., 1992. The transfer of cadmium from agricultural soils to the human food chain. In: Adriano, D.C. (Ed.), Biogeochemistry of Trace Metals. Lewis, Boca Raton, FL, USA, pp. 109-158.

Khattak, R.A., Page, A.L., 1992. Mechanism of manganese adsorption on soil constituents. In: Adriano, D.C. (Ed.), Biogeochemistry of Trace Metals. Lewis, Boca Raton, FL, USA, pp. 383-400.

Kuo, S., Jellum, E.J., Baker, A.S., 1985. Effects of soil type, liming, and sludge application on $\mathrm{Zn}$ and $\mathrm{Cd}$ availability to swiss chard. Soil Sci. 139, 122-130.

Kuo, S., McNeal, B.L., 1984. Effects of pH and phosphate on cadmium sorption by a hydrous ferric oxide. Soil Sci. Soc. Am. J. 48, 1040-1044.

Lakanen, E., Ervio, R., 1971. A comparison of eight extractants for the determination of plant available micronutrients in soils. Acta Agric. Chem. 123, 223-232.

Lee, G.J., 1996. The assessment of remediation techniques by chemical treatments for soils contaminated with cadmium and lead. Master Thesis. Graduate Institute of Agricultural Chemistry, National Taiwan University, Taipei, Taiwan, p. 130 (in Chinese, with English abstract).

Lee, D.Y., Chen, Z.S., 1994. Plants for cadmium polluted soils in northern Taiwan. In: Adriano, D.C., Chen, Z.S., Yang, S.S. (Eds.), Biogeochemistry of Trace Elements. A special issue of Environmental Geochemistry and Health 16, pp. $161-170$.

Liu, J.C., Looi, K.S., Chen, Z.S., Lee, D.Y., 1998. The effects of composts and calcium carbonate on the uptake of cadmium and lead by vegetables grown in polluted soils. J. Chinese Insti. Environ. Engrg. 8, 53-60.

Ma, L.Q., Rao, G.N., 1997. Chemical fractionation of cadmium, copper, nickel, and zinc in contaminated soils. J. Environ. Qual. 26, 259-264.

McBride, M.B., 1980. Chemisorption of $\mathrm{Cd} \pi$ on calcite surfaces. Soil Sci. Soc. Am. J. 44, 26-28.

McBride, M.B., Blasiak, J.J., 1979. Zinc and copper solubility as a function of $\mathrm{pH}$ in an acid soil. Soil Sci. Soc. Am. J. 43, 866-870. 
McKenzie, R.M., 1980. The adsorption of lead and other heavy metals on oxides of manganese and iron. Aust. J. Soil Res. 18, 61-73.

McLean, E.O., 1982. Soil pH and lime requirement. In: Page et al., A.L. (Eds.), Methods of Soil Analysis, Part 2. Chemical and Microbiological Properties, Second ed., Agronomy Monograph No. 9, pp. 199-224.

Mench, M.J., Didier, V.L., Loffler, M., Gomez, A., Masson, P., 1994. A mimicked in-situ remediation study of metalcontaminated soils with emphasis on cadmium and lead. J. Environ. Qual. 23, 58-63.

Naidu, R., Bolan, N.S., Kookana, R.S., Tiller, K.G., 1994. Ionic-strength and $\mathrm{pH}$ effects on the sorption of cadmium and the surface charge of soils. European J. Soil Sci. 45, 419-429.

Nelson, D.W., Sommers, L.E., 1982. Total carbon, organic carbon, and organic matter. In: Page et al., A.L. (Ed.), Methods of Soil Analysis, Part 2. Chemical and Microbiological Properties, Second ed., Agronomy Monograph No. 9, pp. 539-577.

Norvell, W.A., 1984. Comparison of chelating agents as extractants for metals in diverse soil materials. Soil Sci. Soc. Am. J. 48, 1285-1292.

Purves, D., 1985. Trace-Element Contamination of the Environment. Elsevier, Amsterdam, The Netherlands.
Rhoades, J.D., 1982. Cation exchange capacity. In: Page et al., A.L. (Ed.), Methods of Soil Analysis, Part 2. Chemical and Microbiological Properties. Second ed., Agronomy Monograph No. 9, pp. 149-157.

SAS Institute, 1982. SAS user's guide. Statistics. SAS Inst, Cary, NC, USA.

Sommers, L.E., Lindsay, W.L., 1979. Effect of $\mathrm{pH}$ and redox on predicted heavy metal-chelate equilibria in soils. Soil Sci. Soc. Am. J. 43, 39-47.

Tiller, K.G., Gerth, J., Bruemmer, G.W., 1984. The relative affinities of $\mathrm{Cd}, \mathrm{Ni}$, and $\mathrm{Zn}$ for different clay fraction and goethite. Geoderma. 34, 17-35.

Wang, Y.P., Chen, Z.S., Li, K.C., Lin, H.T., Huang, Y.M., Liu, C.L., 1994. Assessment of soil pollution and soil remediation techniques tested in the polluted soils of Taiwan. Project report of EPA-ROC (Grant No. EPA-83H105-09-04). Taipei, Taiwan (in Chinese, with English abstract).

Xian, X., 1987. Chemical partitioning of cadmium, zinc, lead, and copper in soils near smelters. J. Environ. Sci. Health 6, 527-541.

Xian, X., 1989. Effect of chemical forms of cadmium, zinc, and lead in polluted soils on their uptake by cabbage plants. Plant and Soil 113, 257-264. 